\title{
Watermelon Stubble [Citrullus lanatus (Thunb.) Matsum. \& Nakai] as a Substrate for Pleurotus spp. Cultivation in Mexico
}

\author{
Maricela Cayetano-Catarino, Teodoro Bernabé-González*, Gadiel Bernabé-Villanueva, \\ Adalid Romero-Flores, Ana P. Laureano-Guadarrama and Jesús E. De la Cruz-Memije
}

Higher School of Natural Sciences, Autonomous University of Guerrero, Mexico. Biotechnology of Edible and Medicinal Mushrooms

*Corresponding author

\section{A B S T R A C T}

\section{Keywords}

Agricultural residues, Edible mushrooms, Mushroom cultivation, Oyster mushroom, Pleurotus, Solid fermentation

\section{Article Info}

Accepted: 18 May 2020 Available Online: 10 June 2020
The cultivation of Pleurotus species occupies the second place of production worldwide after Agaricus bisporus (J.E. Lange) Imbach. In Mexico, agricultural by-products have been used as a substrate in the cultivation of Pleurotus spp. So, watermelon stubble potential as a substrate in the cultivation of three Pleurotus strains, named IE-4 [P. pulmonarius (Fr.) Quél.,], IE-8 [P. ostreatus (Jacq.:Fr.) Kumm.] and IE-116 [P. djamor (Rumph.: Fr.) Boedijn], was studied. Days in the formation of first fruiting primordia, total cycle days, averages of three harvests, pileus diameter (three groups G1: $\langle 5 \mathrm{~cm} ; \mathrm{G} 2: 5$ to $9.9 \mathrm{~cm}$; G3: $>10 \mathrm{~cm}$ ), biological efficiency $(\mathrm{BE})$, production rate $(\mathrm{PR})$ and yield $(\mathrm{Y})$ were evaluated. First primordia were formed between 15 and 21 days after spawning with a total cycle between 33 and 48 days. G1 predominated followed by G2. IE-4 and IE-8 strains reached the highest weight of fresh mushrooms, with BE of $157.0 \%$ and $164.4 \%$; PR of 3.7\% in both; Y of $36.1 \%$ and $37.8 \%$, followed by IE-116 strain with BE of $122.4 \%$; PR of $3.4 \%$; Y of $28.2 \%$. Watermelon stubble proved to be a good substrate for the cultivation of Pleurotus species, preferably in the regions where it is discarded.

\section{Introduction}

Mexico produces a wide variety of vegetables, fruits, and seeds. Among the fruits, watermelon melon [Citrullus lanatus (Thunb.) Matsum. \& Nakai] stands out because,in 2018, 1'472,459.29 tons were produced by 26 of its states (SIAP, 2018). Once harvested the fruits, the plant stubble remains in the farmland without any application.

An alternative to taking advantage of agricultural by-products is using them as a substrate in the artificial cultivation of edible mushrooms, mainly with Pleurotus spp., which ranked second in commercial production worldwide (Royse et al., 2017). In 
Mexico, the species most cultivated are $P$. ostreatus and $P$. pulmonarius for good development under moderate temperatures (Gaitán-Hernández and Salmones, 2008; Royse and Sánchez, 2017) and represent $4.76 \%$ of the total generated in Latin American (Martinez-Carrera et al., 2016). Therefore, in this study, the production of three strains of Pleurotus on waste plant watermelon was evaluated, to know its potential application for the cultivation of edible mushrooms at the level of selfconsumption or commercial.

\section{Materials and Methods}

The experimentation was carried out in a pilot plant at the Superior School of Natural Sciences of the Autonomous University of Guerrero, Mexico.

\section{Strains and spawn preparation}

The studied strains were IE-4 (Pleurotus pulmonarius), IE-8 (P. ostreatus) and IE-116 (P. djamor) and are deposited at the Ceparium of the Institute of Ecology in Xalapa, Mexico. Strains were maintained on potato dextrose agar (PDA, Bioxon) between $27^{\circ} \mathrm{C}$ and $28^{\circ} \mathrm{C}$ in the dark.

The spawn was prepared with hydrated wheat grain (Triticum aestivum L.) (ca.45\% moisture), placed in heat-resistant polypropylene bags ( $c a .250 \mathrm{~g} / \mathrm{bag}$ ) and sterilized at $121^{\circ} \mathrm{C}$ for $1 \mathrm{~h}$. Subsequently, 1 $\mathrm{cm}^{2}$ of PDA with previously developed mycelium of the three strains was added to each bag and incubated at $28^{\circ} \mathrm{C}$ in the dark for two weeks.

\section{Substrate preparation and spawning}

Semi-wet and green stubble was obtained and fragmented into segments between 3 to $5 \mathrm{~cm}$ and sun dried for two days. Subsequently, it was hydrated for $18 \mathrm{~h}$ and disinfected by pasteurization in hot water at $80^{\circ} \mathrm{C}$ for $1 \mathrm{~h}$. Once cold, it was placed inside polypropylene bags of $50 \times 70 \mathrm{~cm}$, and the spawn $(250 \mathrm{~g})$ was added homogeneously. Each bag weighted $4 \mathrm{~kg}$ wet $(23 \mathrm{~g}$ dry/100 g wet). Seven bags for each strain were prepared and incubated in the dark at room temperature $\left(25^{\circ} \mathrm{C}-27^{\circ} \mathrm{C}\right)$ until the formation of first fruiting primordia.

\section{Harvests and parameters evaluated}

When the first fruiting primordia appeared, the bags were transferred to a production room and placed on metal shelves. The plastic covering the substrate was removed and watered 4 times/day with a manual sprinkler. The lighting was natural, but indirectly through windows (12 h/day). The environmental conditions were from $24^{\circ} \mathrm{C}$ to $28^{\circ} \mathrm{C}$, relative humidity between $80 \%$ and $85 \%$. Ventilation was provided with two electric extractors.

The parameters evaluated were: number of days counted from the spawning to the formation of the first fruiting primordia, total cycle days, three harvests, diameter of the pileus in three groups: G1 $<5 \mathrm{~cm}, \mathrm{G} 2$ from 5 to $9.9 \mathrm{~cm}$ and $\mathrm{G} 3>10 \mathrm{~cm}$, biological efficiency (BE), production rate (PR) and yield (Y) (Gaitán-Hernández and Silva, 2016).

$$
\mathrm{BE}=\frac{\text { Fresh weight of harvested basidiocarps }}{\text { Weight of dry substrate }} \times 100
$$

$\mathrm{PR}=\frac{\mathrm{BE}}{\text { Total production days }} \times 100$

$\mathrm{Y}=\frac{\text { Fresh weight of harvested basidiocarps }}{\text { Weight of wet substrate }} \times 100$ 
Experimental design and statistical analysis

A completely randomized design was used. Data obtained in variables were subjected to analysis of variance and the average values were analyzed with the multiple range test of Tukey $(\alpha=0.05)$.

\section{Results and Discussion}

The first primordia appeared at 14 and 15 days after spawning in the IE-116 strain where as in IE-4 and IE-8 strains were between 16 to 21 days. The production cycle was shorter in IE-116 strain with 33 to 39 days and the longest was for IE-4 strain with 39 to 48 days. All strains reached three harvests. IE-4 and IE- 8 strains accumulated $80 \%$ of production in the first and second harvest, unlike the IE-116 strain that accumulated $73.6 \%$ (Table 1).

In the size of the pileus, the basidiocarps were mostly from G1 (49.1\% to 59.2\%). IE-8 strain produced the highest amount of G1, followed by IE-4 strain in G2 and finally IE-116 strain in G3. The highest average values of BE, PR, and Y were reached by the IE-8 and IE-4 strains, without significant differences between them, and were higher than the values obtained by the IE-116 strain (Table 2).

The values reached in this study with the IE-4 strain, are higher than those when grown on: jicama stubble [Pachyrrhizus erosus (L.) Urb.] dehydrated in the sun (BE 49.89\%; PR $0.8 \%$ ) or fermented for up to 7 days (BE $44.08 \%$ to $78.41 \%$; PR $0.73 \%$ to $1.42 \%$ ); maguey mezcalero bagasse (Agave cupreata Trel. \& Berger) fermented (BE 78.29\%; PR $1.6 \%$ ) or mixed with rice straw (Oryza sativa L.) in 2:1 and 3:1 ratios(BE $111.16 \%$ and $119.88 \%$; PR 2.2 and 2.5\%); rice straw (BE 131.5\%; PR 2.8\%); dry stem of jamaica
(Hibiscus sabdariffa Ulbr.) (BE 64.5\%; Y $20.0 \%$ ) or mixture with rice straw (BE 74.4\%; Y $20.3 \%$ ) and on fermented pseudostem of banana (Musa paradisiaca L.) (BE 96.4\%; Y $14.9 \%$ ) (Cayetano-Catarino and BernabéGonzález, 2008); tomato stubble (Lycopersicum esculentum P. Mill.) (BE 139.8; PR 2.1\%; Y 9.8\%) or mixed with vine wood (Vitis vinifera L.) in 1:1 ratio (BE 107.6\%; PR 1.7\%; Y 7.5\%) or mixed with wheat straw in 1:1 ratio (BE 92.0\%; PR 1.4\%; Y 6.4\%) (Sánchez et al., 2008) and on a mixture of corn stubble (Zea mays L.) and oat straw (Avena sativa L.) in 20\%:80\% proportion (BE 133.1\%; PR 2.0\%) (GaitánHernández and Silva, 2016).

The values of IE- 8 strain are higher than those obtained in other agricultural by products such stem dry jamaica (BE 69.4\%; Y 21.50\%) or mixed with rice straw (BE 81.7\%; Y 22.3\%); pseudostem fermented banana (BE 99.8\%; Y 15.4\%) (Cayetano-Catarino and Bernabé-González, 2008); tomato stubble (BE 118.5; PR 2.9\%; Y8.3\%) or mixed with vine wood in 1:1 ratio (BE 112.4\%; PR 2.8\%; Y $7.9 \%)$ or mixed with wheat straw in $1: 1$ ratio (BE 111.3\%; PR 2.7\%; Y 6.4\%) (Sánchez et al., 2008); bean stubble (Phaseolus vulgaris L.) (BE 46.8\%; PR 0.39\%) or supplemented with dehydrated alfalfa (Medicago sativa $\mathrm{L}$.) in various proportions (BE $62.7 \%$ to $84.1 \%$; PR $0.52 \%$ to $0.70 \%$ ) (Romero-Arenas et al., 2018); wheat straw (BE 38.6\%), paddy straw, sawdust of chir (Pinus roxburghii Sargent) and sawdust of kail (Pinus wallichiana A. B. Jacks.) alone and mixed (BE $0.65 \%$ to $35.27 \%$ ) (Hussain et al., 2020).

Other similar or higher values were obtained in the cultivation of $P$. ostreatus strain on mixtures of wheat straw, waste paper and waste of cotton seeds (Gossypium sp.), in which the first primordia appeared between 22 and 32 days, with BE between $161.3 \%$ and 191.7\% (Getachew et al., 2019). 
Table.1 Formation days of first fruiting primordia, total crops cycle and average mushroom production obtained by three Pleurotus strains cultivated on watermelon stubble

\begin{tabular}{|c|c|c|c|c|c|c|}
\hline \multirow[t]{2}{*}{ Strains } & \multirow[t]{2}{*}{$\mathrm{AFP}^{1}$} & \multirow{2}{*}{$\begin{array}{l}\text { Total crops } \\
\text { cycle (days) }\end{array}$} & \multicolumn{4}{|c|}{ Harvest (g) } \\
\hline & & & First & Second & Third & Total (g) \\
\hline IE-4 & $16-19$ & $39-48$ & $\begin{array}{c}929.2 \\
(64.4) \mathrm{a}^{*}\end{array}$ & $\begin{array}{c}299.4 \\
(20.7) a\end{array}$ & $\begin{array}{c}215.0 \\
(14.9) \mathrm{a}\end{array}$ & $1443.6 \mathrm{a}$ \\
\hline IE-8 & $19-21$ & $43-46$ & $\begin{array}{c}931.7 \\
(61.6) \mathrm{a}\end{array}$ & $\begin{array}{c}337.9 \\
(22.3) \mathrm{a}\end{array}$ & $\begin{array}{c}242.8 \\
(16.1) \mathrm{a}\end{array}$ & $1512.4 \mathrm{a}$ \\
\hline IE-116 & $14-15$ & $33-39$ & $\begin{array}{c}509.9 \\
(45.3) b\end{array}$ & $\begin{array}{c}319.3 \\
(28.3) \mathrm{a}\end{array}$ & $\begin{array}{c}297.1 \\
(26.4) \mathrm{a}\end{array}$ & $1126.3 \mathrm{~b}$ \\
\hline
\end{tabular}

${ }^{1} \mathrm{AFP}=$ appearance of first primordia (days after spawning). Figures in parentheses are percentages. ${ }^{*}$ Different letters in the same column indicate statistical differences between the averages according to Tukey's multiple range test $(\alpha$ $=0.05)$.

Table.2 Average mushroom production by group size and productivity indices obtained by three Pleurotus strains cultivated on watermelon stubble.

\begin{tabular}{|c|c|c|c|c|c|c|}
\hline \multicolumn{4}{|c|}{ Groups by the size of the pileus ( $\mathrm{g}$ ) } & \multicolumn{3}{|c|}{ Productivity indices } \\
\hline Strains & $\begin{array}{c}\text { Group } 1 \\
<5 \mathrm{~cm}\end{array}$ & $\begin{array}{c}\text { Group } 2 \\
\text { of } 5 \text { to } 9.9 \\
\text { cm }\end{array}$ & $\begin{array}{c}\text { Group } 3 \\
>10 \mathrm{~cm}\end{array}$ & $\begin{array}{c}\text { Biological } \\
\text { Efficiency } \\
(\%)\end{array}$ & $\begin{array}{c}\text { Production } \\
\text { Rate }(\%)\end{array}$ & $\begin{array}{c}\text { Yield } \\
(\%)\end{array}$ \\
\hline IE-4 & $\begin{array}{c}708.6 \\
\text { (49.1) ab* }\end{array}$ & $\begin{array}{c}665.9 \\
(46.1) \mathrm{a}\end{array}$ & $\begin{array}{c}69.1 \\
(4.8) \mathrm{ab}\end{array}$ & $157.0 \pm 22.7 \mathrm{a}$ & $3.7 \pm 0.7 \mathrm{a}$ & $36.1 \pm 5.2 \mathrm{a}$ \\
\hline IE-8 & $\begin{array}{c}895.3 \\
(59.2) \mathrm{a}\end{array}$ & $\begin{array}{c}599.3 \\
(39.6) \mathrm{a}\end{array}$ & $\begin{array}{c}17.8 \\
(1.2) b\end{array}$ & $164.4 \pm 20.6 \mathrm{a}$ & $3.7 \pm 0.5 \mathrm{a}$ & $37.8 \pm 4.7 \mathrm{a}$ \\
\hline IE-116 & $\begin{array}{c}619.4 \\
(55.0) \mathrm{b}\end{array}$ & $\begin{array}{c}368.9 \\
(32.8) \mathrm{b}\end{array}$ & $\begin{array}{c}138.0 \\
(12.2) \mathrm{a}\end{array}$ & $122.4 \pm 22.6 \mathrm{~b}$ & $3.4 \pm 0.7 \mathrm{a}$ & $28.2 \pm 5.2 b$ \\
\hline
\end{tabular}

Figures in parentheses are percentages. *Different letters in the same column indicate statistical differences between the averages according to Tukey's multiple range test $(\alpha=0.05)$.

IE-116 strain reached a higher value than that obtained in the cultivation of other $P$. djamor strains. UADY-19 strain was grown on corn stubble (BE 83.9; PR 1.2\%), squash stubble (Cucurbita pepo L.) (BE 71.3\%; PR 1.2\%) and henequen bagasse (Agave fourcroydes Lem.) (BE 76.1\%; PR 2.2\%) (López et al., 2005). RN81 and RN82 strains were grown on rice straw (BE 55.79\%, PR 1.03\%; BE $16.96 \%$, PR 0.36\%), corn stubble (BE
53.16\%, PR 0.98\%; BE 23.14\%, PR 0.40\%) and on tuza corn (BE 62.90\%, PR 1.16\%; BE $15.94 \%$, PR 0.30\%) (Vega and Franco, 2013). Another $P$. djamor strain was cultivated on fresh and dry agro-wastes from soybean (Glycin max L.), chick-pea (Cicer arientinum L.), pigeon-pea [Cajanus cajan (L.) Huth], mung-bean [Vigna mungo (L.) Hepper], wheat and sorghum (Sorghum vulgare Pers.). First primordia formation was between 15 to 
18 days on all substrates. The highest BE was obtained in soybean stubble with $109.8 \%$ and in the others substrates was between $31.0 \%$ and $81.2 \%$ (Deshmukh and Deshmukh, 2016).

Stubble watermelon plant proved to be a potentially suitable substrate for the cultivation of the three strains studied since it exceeded $100 \%$ BE. Therefore, it can be used in the production of Pleurotus species at the level of self-consumption or industrial scale in the regions in which it is generated.

\section{Acknowledgements}

The authors express deep gratitude to Dr. Javier Saldaña Almazán, Rector of the Autonomous University of Guerrero, Mexico, for giving support to this research.

\section{References}

Cayetano-Catarino, M. and T. BernabéGonzález. 2008. Cultivo de Pleurotus sobre residuos de las cosechas de jamaica (Hibiscus sabdariffa) y plátano (Musa paradisiaca). Revista Mexicana de Micología. 26: 57-60.

Deshmukh, S.V. and V.R. Deshmukh. 2016. Soybean straw: A promising substrate for cultivation of oyster mushroom. International Journal of Science and Research. (5)3: 1528-1531.

Gaitán-Hernández, R. and D. Salmones. 2008. Obtaining and characterizing Pleurotus ostreatus strains for commercial cultivation under warm environmental conditions. Scientia Horticulturae. 118(2): 106-110.

Gaitán-Hernández, R. and H.A. Silva. 2016. Aprovechamiento de residuos agrícolas locales para la producción de Pleurotus spp., en una comunidad rural de Veracruz, México. Revista Mexicana de Micología.43: 43-47.

Getachew, A., A. Keneni and M. Chawaka.
2019. Production of oyster mushroom (Pleurotus ostreatus) on substrate composed from wheat straw, waste paper and cotton seed waste. International Journal of Microbiology and Biotechnology.4(2): 38-44.

Hussain, A.A., A. Hamid, N.M. Muazzan, S.A.S. Zulfiqar, S. Anjum, K. M. Tariq and M. Ilyas. 2020. Impact of different lignocellulose substrates on growth and yield of oyster mushroom (Pleurous ostreatus). Pure and Applied Biology.9(1): 768-775.

López, C.E.H., L. Ancona M. and S. Medina P. 2005. Cultivo de Pleurotus djamor en condiciones de laboratorio y en una casa rural tropical. Revista Mexicana deMicología. 21: 93-97.

Martínez-Carrera, D., A. Larqué-Saavedra, A. Tovar Palacio, N. Torres, M.E. Meneses, M. Sobal Cruz, P. Morales Almora, M. Bonilla Quintero, $\mathrm{H}$. Escudero Uribe, I. Tello-Salgado, T. Bernabé-González, W. Martínez Sánchez and Y. Mayett. 2016. Contribución de los hongos comestibles, funcionales y medicinales a la construcción de un paradigma sobre la producción, la dieta, la salud y la cultura en el sistema agroalimentario de México. In: Martínez-Carrera D., J. Ramírez Juárez (eds.), Ciencia, Tecnología e Innovación en el Sistema Agroalimentario de México. Editorial del Colegio de Posgraduados-AMCCONACYT-UPAEP-IMINAP, San Luis Huexotla, Texcoco, México, pp. 581-640.

Romero-Arenas, O., M.A. Valencia-De Ita, J.A. Rivera-Tapia, I. Tello-Salgado, O.A. Villarreal Espino-Barros and M.A. Damián-Huato. 2018. Capacidad productiva de Pleurotus ostreatus utilizando alfalfa deshidratada como suplemento en diferentes sustratos agrícolas. Agricultura, Sociedad y 
Desarrollo. 15(2): 145-160.

Royse, D.J. and J.E. Sánchez. 2017. Producción mundial de setas Pleurotus spp. con énfasis en países iberoamericanos. In: Sánchez, J.E., D. Royse (eds.). La biología, el cultivo y las propiedades nutricionales y medicinales de las setas Pleurotus spp. El Colegio de la Frontera Sur. Tapachula, pp. 17-25.

Royse, D.J., J. Baars and Q. Tan. 2017. Current overview of mushroom production in the world. In: Zied, D.C., A. Pardo-Giménez (eds.), Edible and medicinal mushrooms: Technology and applications. John Wiley and SonsBlackwell, Nueva York. Pp. 5-13. http://doi.org/10.1002/9781119149446. $\operatorname{ch} 2$.

Sánchez, A., M. Esqueda, R. Gaitán-
Hernández, A. Córdova and M.L. Coronado. 2008. Uso potencial del rastrojo de tomate como sustrato para el cultivo de Pleurotus spp. Revista Mexicana de Micología.28: 17-24.

SIAP. 2018. Servicio DE Información Agroalimentaria Y Pesquera. Secretaría de Agricultura, Ganadería, Desarrollo rural, Pesca y Alimentación. http://infosiap.siap.gob.mx/gobmx/datos Abiertos_a.php.

Vega, A. and H. Franco. 2013. Productividad y calidad de los cuerpos fructíferos de los hongos comestibles Pleurotus pulmonarius RN2 y P. djamor RN81 y RN82 cultivados sobre sustratos lignocelulósicos. Información Tecnológica. 24(1): 69-78. doi: 10.4067/S0718-07642013000100009.

\section{How to cite this article:}

Maricela Cayetano-Catarino, Teodoro Bernabé-González, Gadiel Bernabé-Villanueva, Adalid Romero-Flores, Ana P. Laureano-Guadarrama and Jesús E. De la Cruz-Memije. 2020. Watermelon Stubble [Citrullus lanatus (Thunb.) Matsum. \& Nakai] as a Substrate for Pleurotus spp. Cultivation in Mexico. Int.J.Curr.Microbiol.App.Sci. 9(06): 1720-1725. doi: https://doi.org/10.20546/ijcmas.2020.906.213 